\title{
Implementasi Model Pembelajaran Stad Berbantuan Lkm Untuk Meningkatkan Hasil Belajar Akuntansi Sektor Publik
}

\author{
Okto Irianto \\ Jurusan Akuntansi, FEB Universitas Musamus Merauke \\ Email : irianto@unmus.ac.id
}

Received: 25 Januari, 2019; Accepted: 27 Maret, 2019; Published: 27 Juni, 2019

\begin{abstract}
Abstrak
Penelitian ini bertujuan untuk mengetahui peningkatan hasil belajar mahasiswa melalui implementasi model pembelajaran STAD berbantuan LKM. Penelitian ini adalah Penelitian Tindakan Kelas (PTK) yang dilaksanakan dalam 3 siklus. Waktu penelitian pada semester ganjil Tahun Ajaran 2018/2019, dengan sampel adalah mahasiswa Jurusan Akuntansi FEB Universitas Musamus, Merauke. Teknik analisis data dalam penelitian ini adalah analisis data deskriptif kuantitatif dengan persentase. Hasil penelitian menunjukkan bahwa Implementasi Model Pembelajaran STAD Berbantuan LKM dapat meningkatkan Hasil Belajar Akuntansi Sektor Publik. Peningkatan dapat dilihat dari nilai rata-rata hasil belajar mahasiswa pada prasiklus sebesar 50,36, meningkat pada siklus I sebesar 61,02, meningkat pada siklus II sebesar 73,07, dan meningkat pada siklus III sebesar 85,31.
\end{abstract}

Kata Kunci : STAD, LKM, hasil belajar, akuntansi sektor publik

\begin{abstract}
This study aims to determine the improvement of student learning outcomes through the implementation of STAD learning model assisted with LKM. This study was a Classroom Action Research (CAR) which was conducted in 3 cycles. Time of study in odd semester Academic Year 2018/2019, with a sample of accounting students at the Faculty of Economics and Business, University of Musamus, Merauke. The data analysis technique in this study is descriptive quantitative data analysis with percentages. The results of the study show that the Implementation of STAD Learning Model Assisted with LKM can improve Public Sector Accounting Learning Outcomes. The increase can be seen from the average value of student learning outcomes on the cycle of 50,36, increasing in the first cycle of 61,02, increasing in the second cycle of 73.07, and increasing in the third cycle of 85,31.
\end{abstract}

Keyword : Learning outcomes LKM, Public sector accounting,STAD 


\section{PENDAHULUAN}

Proses pembelajaran pada hakikatnya adalah proses belajarnya mahasiswa, bukan proses mengajarnya dosen. Hal ini cenderung kurang diperhatikan dalam proses pembelajaran. Sehingga kemudian dikembangkan pembelajaran kooperatif yang merupakan pembelajaran yang berpusat pada mahasiswa. Mahasiswa diarahkan untuk membentuk kelompok-kelompok dengan latar belakang heterogen. Latar belakang yang dimaksud antara lain gender, kinerja akademik, ras, dan etnisitas. Kelompokkelompok mahasiswa dibentuk agar dapat saling membantu dalam penguasaan materi hingga menyelesaikan tugas yang diberikan. Dengan adanya kesamaan bahasa, tingkat perkembangan intelektual dan pengalaman kedekatan antar mahasiswa, akan membuat mahasiswa lebih mudah memahami materi kuliah.

Menurut Rusman (2012) ada lima unsur dasar dalam pembelajaran kooperatif, yaitu tatap muka, ketergantungan positif, pertanggungjawaban individu, kemampuan bersosialisasi, dan evaluasi kelompok. Selain itu terdapat juga empat hal penting dalam pembelajaran kooperatif, yaitu pengelompokkan mahasiswa, aturan main dalam kelompok, upaya belajar dalam kelompok, dan adanya kompetensi yang harus dicapai oleh kelompok.

Salah satu model pembelajaran kooperatif adalah Student Team Achievement Divisions (STAD). Model pembelajaran STAD bertujuan untuk menumbuhkan kemampuan kerjasama, kreatif, berpikir kritis, dan saling membantu dalam kelompok. Dalam penerapannya, terdapat lima komponen utama, yaitu penyajian kelas, kegiatan kelompok, kuis, skor perkembangan individu, dan penghargaan kelompok. Penyajian kelas mencakup pembukaan, pengembangan, dan latihan terbimbing. Kegiatan kelompok mencakup diskusi penyelesaian soal-soal yang diberikan melalui lembar kerja. Kuis mencakup tes mandiri yang dikerjakan oleh mahasiswa sebagai indikator keberhasilan kerja kelompok. Skor perkembangan individu mencakup skor-skor kuis yang menunjukkan peningkatan maupun penurunan kinerja akademik mahasiswa. Penghargaan kelompok mencakup pemberian predikat pada kelompok didasarkan pada skor perkembangan kelompok (Gusniar, 2014). 
Isjoni (2010) menyatakan kelebihan STAD adalah melatih pengembangan aspek kecakapan sosial dan kecakapan kognitif pada siswa. Pada dosen, peran sebagai fasilitator, mediator, motivator dan evaluator menjadi lebih aktif dan lebih terfokus. Sementara menurut Khusna (2011) kelemahan STAD adalah semakin banyak jumlah mahasiswa di dalam kelas maka semakin lama waktu yang dibutuhkan, khususnya pada tahap penyajian materi dari guru, kerja kelompok, dan tes individual/kuis.

Lembar Kerja Mahasiswa (LKM) berupa lembaran kertas yang berisi informasi maupun soal-soal yang harus dijawab oleh mahasiswa. Dalam proses pembelajaran LKM dapat dimanfaatkan pada tahap penanaman konsep (menyampaikan konsep baru) atau pada tahap pemahaman konsep (tahap lanjutan dari penanaman konsep) karena LKM dirancang untuk membimbing mahasiswa dalam mempelajari topik bahasan (Asmaningrum, 2017).

Belajar dengan menggunakan LKM menuntut mahasiswa untuk lebih aktif, baik mental maupun fisik di dalam kegiatan belajar mengajar. Mahasiswa dibiasakan untuk berpikir kritis, logis dan sistematis, karena dituntut mencari informasi sendiri. Penggunaan LKM dapat melatih mahasiswa

untuk menemukan dan mengembangkan keterampilan proses serta memberi pedoman bagi dosen dan mahasiswa dalam pencapaian pemahaman konsep (Sugiharti dkk, 2013 \& Arikunto, 2013).

Matakuliah Akuntansi Sektor Publik adalah matakuliah yang membahas tentang pengawasan dan pelaporan dalam tangka akuntabilitas publik. Tuntutan agar pemerintah dikelola secara profesional dan efisien menyadarkan setiap orang, khususnya aparat pemerintah, untuk senantiasa tanggap dengan dinamika lingkungannya dan berupaya dalam pelayanan terbaik secara transparan dan akuntabel (Nordiawan dan Hertianti, 2010).

\section{METODE PENELITIAN}

Jenis penelitian ini merupakan Penelitian Tindakan Kelas (PTK). Penelitian Tindakan Kelas merupakan penelitian yang menjadikan hal-hal yang terjadi di 
masyarakat sebagai objek penelitian dan hasil penelitian dapat langsung dirasakan oleh sampel penelitian (Suharsimi, 2013: 129). Penelitian Tindakan Kelas terdiri dari beberapa siklus. Setiap siklus terdapat empat langkah yaitu perencanaan, pelaksanaan, pengamatan, dan observasi. Dalam pelaksanaannya peneliti berkolaborasi bersama observer.

Subjek penelitian adalah mahasiswa Jurusan Akuntansi yang mengambil matakuliah Akuntansi Sektor Publik Kelas A sebanyak 45 orang. Objek penelitian adalah hasil belajar pada matakuliah Akuntansi Sektor Publik setelah implementasi model pembelajaran STAD berbantuan LKM.

Prosedur penelitian ini mengikuti tahap-tahap penelitian tindakan kelas yang terdiri dari tiga siklus. Setiap siklus terdiri dari tahap perencanaan, pelaksanaan, observasi, dan refleksi. Tahap-tahap tersebut dijelaskan sebagai berikut :

a. Siklus I

1) Perencanaan

Pada tahap perencanaan ini rencana tindakan yang dilakukan yaitu peneliti menyusun Rencana Pembelajaran Semester (RPS), membentuk kelompok, dan menyusun materi.

2) Pelaksanaan Tindakan

Pada tahap ini, peneliti melaksanakan kegiatan pembelajaran menggunakan model pembelajaran STAD berbantuan LKM.

3) Observasi

Observasi dilakukan oleh peneliti bersama observer. Observasi dilakukan selama proses pembelajaran, menggunakan lembar observasi dan catatan lapangan. Hal-hal yang menjadi objek observasi adalah aktivitas dosen dan aktivitas mahasiswa. 4) Refleksi

Hasil observasi ditindaklanjuti dengan analisis, pemaknaan, penjelasan dan penyimpulan data. Hasil kesimpulan yang didapat berupa data aktivitas dosen, aktivitas mahasiswa, dan kendala-kendala yang dihadapi di lapangan selama implementasi 
model pembelajaran STAD berbantuan LKM pada proses pembelajaran. Hasil yang diperoleh dijadikan dasar untuk melakukan perencanaan pada siklus berikutnya.

b. Siklus II

Siklus II merupakan perbaikan atau penyempurnaan dari siklus I. Tahap-tahap siklus II disusun setelah siklus I selesai dilaksanakan. Diharapkan perbaikan dan penyempurnaan pada siklus II dapat memberikan hasil yang lebih baik.

c. Siklus III

Siklus III merupakan perbaikan atau penyempurnaan dari siklus II. Siklus III dilakukan karena hasil yang diperoleh pada siklus II belum memenuhi indikator keberhasilan penelitian.

\section{Teknik dan Instrumen Pengumpulan Data}

Teknik pengumpulan data pada penelitian ini melalui observasi dan dokumentasi. Observasi adalah pengamatan dengan dengan menggunakan penglihatan, penciuman, pendengaran, perabaan, atau bila diperlukan dengan pengecapan (Trianto, 2011: 267). Objek observasi dalam penelitian ini adalah aktivitas mahasiswa dan aktivitas dosen. Instrumen yang digunakan adalah angket aktivitas mahasiswa dan angket aktivitas dosen.

Data yang dianalisis pada penelitian ini adalah data kuantitatif dan data kualitatif. Data kuantitatif berupa hasil belajar kognitif, dianalisis dengan menggunakan teknik analisis deskriptif dengan menentukan mean atau rerata. Langkah-langkah analisis data kuantitatif menurut Asmaningrum dkk, 2018 antara lain

a. Menentukan nilai berdasarkan skor teoritis

$\mathrm{N}=\frac{b}{s t} \mathrm{X} 100$

Dimana:

$\mathrm{N}=$ Nilai

$\mathrm{b}=$ Skor yang diperoleh

st $=$ Skor teoritis yaitu skor maksimal 
b. Menghitung mean/rerata kelas

$$
\overline{\mathrm{X}}=\frac{\sum \mathrm{x}}{\sum \mathrm{N}}
$$

Dimana :

$\overline{\mathrm{X}}=$ Nilai rata - rata

$\Sigma \mathrm{x}=$ Jumlah semua nilai siswa

$\Sigma \mathrm{N}=$ Jumlah siswa

Data kualitatif berupa data hasil observasi aktivitas mahasiswa dan aktivitas dosen dalam pembelajaran Akuntansi Sektor Publik melalui model pembelajaran STAD berbantuan LKM. Perhitungan data kualitatif didapat dari pengolahan data yang bersumber dari instrumen observasi aktivitas mahasiswa dan aktivitas dosen. Rumus perhitungan data kualitatif ditunjukkan di bawah ini

Skor aktivitas $=\frac{\text { skor total tiap indikator }}{\text { skor maksimal }} \times 100$

Dimana

$>$ NR $90 \%$ sangat baik

$<$ NR $90 \%-70 \%$ baik

$<$ NR $70 \%-50 \%$ cukup

$<$ NR $50 \%-30 \%$ kurang

$<$ NR 30\% -10\% sangat kurang

(Depdiknas, 2006: 37)

Indikator keberhasilan penelitian ini antara lain :

(1) Adanya peningkatan hasil belajar mahasiswa mencapai nilai rata-rata 85

(2) Adanya peningkatan aktivitas mahasiswa mencapai $80 \%$

(3) Adanya peningkatan aktivitas dosen mencapai $85 \%$

\section{HASIL PENELITIAN DAN PEMBAHASAN}

Penelitian ini dilaksanakan sebanyak 3 siklus dengan masing-masing siklus terdiri dari 3 pertemuan. Berikut dipaparkan mengenai hasil penelitian yang terdiri atas 
hasil belajar mahasiswa, hasil observasi aktivitas mahasiswa, dan hasil observasi aktivitas dosen melalui implementasi model pembelajaran STAD berbantuan LKM.

\section{Prasiklus}

Tahap prasiklus dilaksanakan pada tanggal 4 Oktober 2018. Pada tahap prasiklus, peneliti menyampaikan materi pembelajaran pada topik regulasi dan standar di sektor publik menggunakan metode konvensional. Selama proses pembelajaran mahasiswa pasif, cenderung tidak memperhatikan, bahkan ada yang terpantau sedang mengerjakan tugas matakuliah lain. Pada sesi tanya jawab, mahasiswa tidak mampu menjawab pertanyaan dari dosen. Juga tidak ada mahasiswa yang mengajukan pertanyaan kepada dosen. Setelah proses pembelajaran selesai, mahasiswa diberi tes untuk mengukur pemahaman mahasiswa. Data hasil belajar mahasiswa ditunjukkan pada Tabel 1.

Tabel 1. Data hasil belajar pretes

\begin{tabular}{ccc}
\hline No & Pencapaian & Prasiklus \\
\hline 1 & Nilai Terendah & 35 \\
\hline 2 & Nilai Tertinggi & 67 \\
\hline 3 & Rata-rata Kelas & 50,36
\end{tabular}

Metode pembelajaran yang berpusat kepada dosen membuat mahasiswa cepat

merasa bosan. Sehingga hasil pembelajaran menjadi kurang bermakna (Saraswati dan Djazari, 2018) bahkan kurang dapat dipahami dalam jangka waktu lama.

\section{Siklus I}

Tahap siklus I dimulai dengan perencanaan. Peneliti merencanakan dan merancang RPS dan LKM sesuai dengan tujuan pembelajaran pada siklus I.

Pelaksanaan tahap siklus I dilaksanakan pada tanggal 8, 11, dan 15 Oktober 2018. Topik yang dipelajari pada siklus I pertemuan 1 dan 2 adalah organisasi sektor publik yang berupa pemerintah, universitas, dan rumah sakit. Pada tahap siklus I, dosen melakukan apersepsi, menyampaikan tujuan pembelajaran, dan menjelaskan langkahlangkah STAD. Dosen membentuk kelompok-kelompok sesuai kriteria model pembelajaran STAD dengan jumlah mahasiswa 5 orang dalam setiap kelompok. Pada 
pertemuan 3, mahasiswa diberi tes untuk mengetahui pemahaman mahasiswa. Data hasil belajar mahasiswa ditunjukkan pada Tabel 2 .

Tabel 2. Data hasil belajar siklus I

\begin{tabular}{ccc}
\hline No & Pencapaian & Siklus I \\
\hline 1 & Nilai Terendah & 50 \\
\hline 2 & Nilai Tertinggi & 75 \\
\hline 3 & Rata-rata Kelas & 61,02
\end{tabular}

Setelah implementasi model pembelajaran STAD berbantuan LKM, hasil belajar mahasiswa meningkat. Nilai rata-rata yang diperoleh 50,36 pada pretes naik menjadi 61,02 pada siklus I. Hal ini menunjukkan bahwa mahasiswa lebih dapat memahami materi pembelajaran melalui model pembelajaran STAD. Nikmah dkk (2013) menyatakan bahwa model pembelajaran STAD menitikberatkan pada kerjasama dalam kelompok belajar. Dengan demikian mahasiswa dituntut untuk saling membantu, memberi motivasi, dan saling percaya satu sama lain. Hal ini memberi kesempatan kepada mahasiswa untuk belajar bekerjasama, berbagi pendapat, pengetahuan, pengalaman, mendengarkan pendapat orang lain, saling memotivasi, dan aktif dalam kegiatan pembelajaran.

Pada saat proses pembelajaran berlangsung, observer mengamati aktivitas mahasiswa. Data aktivitas mahasiswa siklus I ditunjukkan pada Tabel 3.

Tabel 3. Data aktivitas mahasiswa siklus I

\begin{tabular}{clcc}
\hline Tahap & \multicolumn{1}{c}{ Indikator } & $\begin{array}{c}\text { Skor per- } \\
\text { olehan }\end{array}$ & $\begin{array}{c}\text { Skor mak- } \\
\text { simal }\end{array}$ \\
\hline \multirow{2}{*}{ Awal } & Mahasiswa mendengarkan tujuan & 121 & 180 \\
\cline { 2 - 4 } & $\begin{array}{l}\text { Mahasiswa memperhatikan informasi yang disampaikan } \\
\text { dosen }\end{array}$ & 126 & 180 \\
\hline Inti & $\begin{array}{l}\text { Mahasiswa memperhatikan materi yang disampaikan oleh } \\
\text { dosen }\end{array}$ & 121 & 180 \\
\cline { 2 - 4 } & Mahasiswa mengajukan pertanyaan & 112 & 180 \\
\cline { 2 - 4 } & $\begin{array}{l}\text { Mahasiswa mengambil tempat berdasarkan kelompok } \\
\text { yang } \\
\text { dibentuk oleh dosen dan belajar dalam kelompok }\end{array}$ & 113 & 180 \\
\cline { 2 - 4 } Akhir & $\begin{array}{l}\text { Mahasiswa mengerjakan LKM dan melakukan diskusi } \\
\text { aktif dalam diskusi kelompok }\end{array}$ & 123 & 180 \\
\hline
\end{tabular}




\begin{tabular}{|c|c|c|c|}
\hline \multicolumn{2}{|r|}{$\begin{array}{l}\text { Mahasiswa berusaha memperoleh hasil belajar yang lebih } \\
\text { baik dan penghargaan dari guru baik secara individu } \\
\text { maupun kelompok }\end{array}$} & 99 & 180 \\
\hline \multicolumn{2}{|r|}{ Total Skor } & \multicolumn{2}{|c|}{934} \\
\hline \multicolumn{2}{|r|}{ Skor rata-rata } & \multicolumn{2}{|c|}{20,76} \\
\hline \multicolumn{2}{|r|}{ Persentase rata-rata } & \multicolumn{2}{|c|}{$64,86 \%$} \\
\hline \multicolumn{2}{|r|}{ Kategori } & \multicolumn{2}{|c|}{ Cukup } \\
\hline \multicolumn{4}{|c|}{$\begin{array}{l}\text { Pada siklus I, mahasiswa mulai menunjukkan keaktifan baik dalam kelompok } \\
\text { in dalam kelas secara keseluruhan. Namun masih terdapat kelompok yang kurang } \\
\text { langkah-langkah pembelajaran STAD, sehingga hasil yang dicapai secara } \\
\text { du maupun kelompok menjadi kurang maksimal. Aktivitas mahasiswa siklus I } \\
\text { r berada pada 64,86\% yang termasuk dalam kategori cukup. }\end{array}$} \\
\hline \multicolumn{4}{|c|}{$\begin{array}{l}\text { Selain aktivitas mahasiswa, observer juga mengamati aktivitas dosen selama } \\
\text { pembelajaran siklus I. Data aktivitas dosen siklus I ditunjukkan pada Tabel } 4 \text {. } \\
\text { 4. Data aktivitas dosen siklus I }\end{array}$} \\
\hline Tahap & Indikator & $\begin{array}{c}\text { Skor per- } \\
\text { olehan }\end{array}$ & $\begin{array}{l}\text { Skor mak- } \\
\text { simal }\end{array}$ \\
\hline \multirow{2}{*}{ Awal } & Menyampaikan tujuan & 3 & 32 \\
\hline & Memotivasi mahasiswa & 3 & 32 \\
\hline \multirow[t]{4}{*}{ Inti } & Menjelaskan materi pelajaran & 4 & 32 \\
\hline & Memberikan kesempatan bertanya kepada mahasiswa & 3 & 32 \\
\hline & $\begin{array}{l}\text { Membentuk kelompok mahasiswa dan membimbing } \\
\text { mahasiswa dalam belajar }\end{array}$ & 3 & 32 \\
\hline & $\begin{array}{l}\text { Membagikan LKM dan mahasiswa mengisi LKM dan } \\
\text { membimbing mahasiswa dalam melakukan diskusi }\end{array}$ & 3 & 32 \\
\hline \multirow[t]{5}{*}{ Akhir } & $\begin{array}{l}\text { Memberikan evaluasi kepada seluruh mahasiswa baik } \\
\text { secara individu maupun kelompok }\end{array}$ & 3 & 32 \\
\hline & $\begin{array}{l}\text { Memberikan penghargaan kepada mahasiswa baik upaya } \\
\text { maupun hasil belajar individu dan kelompok }\end{array}$ & 3 & 32 \\
\hline & Total Skor & \multicolumn{2}{|c|}{26} \\
\hline & Persentase rata-rata & \multicolumn{2}{|c|}{$\mathbf{7 8 , 1 3 \%}$} \\
\hline & Kategori & \multicolumn{2}{|c|}{ Baik } \\
\hline
\end{tabular}

Pada siklus I, dosen menjelaskan tujuan pembelajaran dan menyampaikan materi dengan jelas dan sistematis. Sehingga mahasiswa memahami tujuan belajar tiap 
pertemuan. Karena mahasiswa masih banyak yang kurang paham mengenai pembelajaran denagn model STAD, maka dosen tampak kewalahan dalam menjelaskan pada kelompok-kelompok mahasiswa. Efisiensi waktu menjadi sangat kurang. Lebih banyak untuk menjelaskan model pembelajaran daripada meningkatkan kualitas materi. Dari hasil pengamatan observer, aktivitas dosen berada pada $81,25 \%$ yang termasuk dalam kategori baik.

Dosen diharapkan dapat menciptakan lingkungan belajar yang dapat meningkatkan keterlibatan mahasiswa secara langsung dan bertanggung jawab terhadap kegiatan belajar. Belajar dengan baik dapat diciptakan apabila dosen dapat mengorganisir suasana kelas melalui variasi model pembelajaran sehingga dapat memengaruhi proses dan hasil belajar mahasiswa (Esminarto dkk, 2016).

Setelah pelaksanaan siklus I selesai, dosen yang juga merupakan peneliti dan observer melakukan refleksi untuk pelaksanaan siklus II. Adapun hasil refleksi dari siklus I antara lain revisi penyusunan LKM menjadi lebih sederhana dan pengelolaan waktu pembelajaran menjadi lebih efisien.

\section{Siklus II}

Sama seperti pada tahap siklus I, tahap siklus II juga dimulai dengan perencanaan. Peneliti merencanakan dan merancang RPS dan LKM sesuai dengan tujuan pembelajaran pada siklus II.

Tahap siklus II dilaksanakan pada tanggal 2, 9, dan 16 November 2018. Topik yang dipelajari pada siklus II pertemuan 1 dan 2 adalah organisasi sektor publik yang berupa yayasan dan partai politik. Pada tahap siklus II, dosen melakukan apersepsi, menyampaikan tujuan pembelajaran, dan menjelaskan kembali langkah-langkah STAD. Dosen membentuk kelompok-kelompok sesuai kriteria model pembelajaran STAD dengan jumlah 4 mahasiswa dalam tiap kelompok. Pada pertemuan 3, mahasiswa diberi tes untuk mengetahui pemahaman mahasiswa. Data hasil belajar mahasiswa ditunjukkan pada Tabel 5.

Tabel 5. Data hasil belajar siklus II

\begin{tabular}{lll}
\hline No & Pencapaian & Siklus II \\
\hline
\end{tabular}




\begin{tabular}{ccc}
\hline 1 & Nilai Terendah & 60 \\
\hline 2 & Nilai Tertinggi & 82 \\
\hline 3 & Rata-rata Kelas & 73,07 \\
\hline
\end{tabular}

Pada saat proses pembelajaran siklus II berlangsung, observer mengamati aktivitas mahasiswa. Data aktivitas mahasiswa siklus II ditunjukkan pada Tabel 6.

Tabel 6. Data aktivitas mahasiswa siklus II

\begin{tabular}{|c|c|c|c|}
\hline Tahap & Indikator & $\begin{array}{c}\text { Skor per- } \\
\text { olehan }\end{array}$ & $\begin{array}{c}\text { Skor mak- } \\
\text { simal }\end{array}$ \\
\hline \multirow[b]{2}{*}{ Awal } & Mahasiswa mendengarkan tujuan & 133 & 180 \\
\hline & $\begin{array}{l}\text { Mahasiswa memperhatikan informasi } \\
\text { yang disampaikan dosen }\end{array}$ & 142 & 180 \\
\hline \multirow{4}{*}{ Inti } & $\begin{array}{l}\text { Mahasiswa memperhatikan materi yang disampaikan oleh } \\
\text { dosen }\end{array}$ & 140 & 180 \\
\hline & Mahasiswa mengajukan pertanyaan & 129 & 180 \\
\hline & $\begin{array}{l}\text { Mahasiswa mengambil tempat berdasarkan kelompok yang } \\
\text { dibentuk oleh dosen dan belajar dalam kelompok }\end{array}$ & 131 & 180 \\
\hline & Mahasiswa mengerjakan LKM dan melakukan diskusi & 127 & 180 \\
\hline \multirow{6}{*}{ Akhir } & $\begin{array}{l}\text { Mahasiswa menjawab tugas yang diberikan dosen dan aktif } \\
\text { dalam diskusi kelompok }\end{array}$ & 142 & 180 \\
\hline & $\begin{array}{l}\text { Mahasiswa berusaha memperoleh hasil belajar yang lebih } \\
\text { baik dan penghargaan dari guru baik secara individu maupun } \\
\text { kelompok }\end{array}$ & 124 & 180 \\
\hline & Total Skor & \multicolumn{2}{|c|}{1068} \\
\hline & Skor rata-rata & \multicolumn{2}{|c|}{23,73} \\
\hline & Persentase rata-rata & \multicolumn{2}{|c|}{$74,17 \%$} \\
\hline & Kategori & \multicolumn{2}{|c|}{ Baik } \\
\hline
\end{tabular}

Pada siklus II aktivitas mahasiswa mengalami peningkatan yang signifikan.

Aktivitas mahasiswa pun lebih produktif pada penyelesaian LKM melalui kegiatankegiatan diskusi. Berdasarkan hasil pengamatan observer, persentase rata-rata aktivitas mahasiswa adalah $74,17 \%$ berada pada kategori baik. Penyusunan LKM yang lebih menarik serta pemberian penghargaan pada kelompok yang berhasil meraih nilai terbaik, memberikan motivasi tersendiri bagi mahasiswa untuk menjadi kelompok terbaik maupun individu terbaik.

Seperti pada siklus I, observer juga mengamati aktivitas dosen pada siklus II. Data aktivitas dosen siklus II ditunjukkan pada Tabel 7. 
Tabel 7. Data aktivitas dosen siklus II

\begin{tabular}{clcc}
\hline \multirow{2}{*}{ Tahap } & \multicolumn{1}{c}{ Indikator } & $\begin{array}{c}\text { Skor } \\
\text { per- } \\
\text { olehan }\end{array}$ & $\begin{array}{c}\text { Skor mak- } \\
\text { simal }\end{array}$ \\
\hline \multirow{2}{*}{ Awal } & Menyampaikan tujuan & 4 & 32 \\
\cline { 2 - 4 } Inti & Memotivasi mahasiswa & 3 & 32 \\
\cline { 2 - 4 } & Menjelaskan materi pelajaran & 4 & 32 \\
\cline { 2 - 4 } & Memberikan kesempatan bertanya kepada mahasiswa & 3 & 32 \\
\cline { 2 - 4 } & $\begin{array}{l}\text { Membentuk kelompok mahasiswa dan membimbing } \\
\text { mahasiswa dalam belajar }\end{array}$ & 4 & 32 \\
\cline { 2 - 5 } & $\begin{array}{l}\text { Membagikan LKM dan mahasiswa mengisi LKM dan } \\
\text { membimbing mahasiswa dalam melakukan diskusi }\end{array}$ & 3 & 32 \\
\hline \multirow{2}{*}{ Akhir } & $\begin{array}{l}\text { Memberikan evaluasi kepada seluruh mahasiswa baik } \\
\text { secara individu maupun kelompok }\end{array}$ & 3 & 32 \\
\cline { 2 - 5 } & $\begin{array}{l}\text { Memberikan penghargaan kepada mahasiswa baik upaya } \\
\text { maupun hasil belajar individu dan kelompok }\end{array}$ & 3 & \multirow{2}{2}{ Total Skor } \\
\hline \multirow{2}{*}{ Persentase rata-rata } & $\mathbf{2 4 , 3 8 \%}$ \\
\hline \multirow{2}{*}{ Kategori } & \multicolumn{2}{|c}{ Baik } \\
\hline
\end{tabular}

Pada siklus II, aktivitas dosen terukur pada persentase rata-rata $84,38 \%$ termasuk pada kategori baik. Hal ini ditunjukkan dari peningkatan dosen dalam mengelola kelas, seperti peningkatan skor pada indikator membentuk dan membimbing kelompok mahasiswa.

Pada tahap refleksi, proses pembelajaran siklus II berjalan lebih baik daripada siklus I. Hal ini ditunjukkan dari adanya peningkatan pada hasil belajar dan aktivitas mahasiswa, serta pada aktivitas dosen. Meskipun telah terjadi peningkatan pada nilai rata-rata hasil belajar, aktivitas mahasiswa, dan aktivitas dosen, namun hasil yang dicapai belum memenuhi indikator keberhasilan. Sehingga perlu dilakukan perbaikan pada siklus III.

\section{Siklus III}

Seperti pada tahap siklus II, tahap siklus III juga dimulai dengan perencanaan. Peneliti merencanakan dan merancang RPS dan LKM sesuai dengan tujuan pembelajaran pada siklus III. 
Tahap siklus III dilaksanakan pada tanggal 23 dan 30 November 2018, serta tanggal 7 Desember 2018. Topik yang dipelajari pada siklus III pertemuan 1 dan 2 adalah konsep anggaran sektor publik. Pada tahap siklus III, dosen melakukan apersepsi dan menyampaikan tujuan pembelajaran. Dosen membentuk kelompok-kelompok sesuai kriteria model pembelajaran STAD dengan jumlah 4 mahasiswa dalam tiap kelompok. Pada pertemuan 3, mahasiswa diberi tes untuk mengetahui pemahaman mahasiswa. Data hasil belajar mahasiswa ditunjukkan pada Tabel 8.

Tabel 8. Data hasil belajar siklus III

\begin{tabular}{ccc}
\hline No & Pencapaian & Siklus III \\
\hline 1 & Nilai Terendah & 79 \\
\hline 2 & Nilai Tertinggi & 93 \\
\hline 3 & Rata-rata Kelas & 85,31 \\
\hline
\end{tabular}

Pada saat proses pembelajaran berlangsung, observer mengamati aktivitas mahasiswa dan aktivitas dosen. Data aktivitas mahasiswa siklus III ditunjukkan pada Tabel 9.

Tabel 9. Data aktivitas siswa siklus III

\begin{tabular}{|c|c|c|c|}
\hline Tahap & Indikator & $\begin{array}{c}\text { Skor per- } \\
\text { olehan }\end{array}$ & $\begin{array}{c}\text { Skor } \\
\text { maksimal }\end{array}$ \\
\hline \multirow{2}{*}{ Awal } & Mahasiswa mendengarkan tujuan & 165 & 180 \\
\hline & Mahasiswa memperhatikan informasi yang disampaikan dosen & 160 & 180 \\
\hline \multirow{4}{*}{ Inti } & Mahasiswa memperhatikan materi yang disampaikan oleh dosen & 151 & 180 \\
\hline & Mahasiswa mengajukan pertanyaan & 150 & 180 \\
\hline & $\begin{array}{l}\text { Mahasiswa mengambil tempat berdasarkan kelompok yang } \\
\text { dibentuk oleh dosen dan belajar dalam kelompok }\end{array}$ & 154 & 180 \\
\hline & Mahasiswa mengerjakan LKM dan melakukan diskusi & 148 & 180 \\
\hline \multirow{6}{*}{ Akhir } & $\begin{array}{l}\text { Mahasiswa menjawab tugas yang diberikan dosen dan aktif } \\
\text { dalam diskusi kelompok }\end{array}$ & 153 & 180 \\
\hline & $\begin{array}{l}\text { Mahasiswa berusaha memperoleh hasil belajar yang lebih baik } \\
\text { dan penghargaan dari guru baik secara individu maupun } \\
\text { kelompok }\end{array}$ & 145 & 180 \\
\hline & Total Skor & \multicolumn{2}{|c|}{1226} \\
\hline & Skor rata-rata & \multicolumn{2}{|c|}{27,24} \\
\hline & Persentase rata-rata & \multicolumn{2}{|c|}{$85,14 \%$} \\
\hline & Kategori & \multicolumn{2}{|c|}{ Baik } \\
\hline
\end{tabular}


Pada siklus III aktivitas mahasiswa juga mengalami peningkatan yang signifikan. Aktivitas mahasiswa semakin produktif selain pada penyelesaian LKM juga meningkat pada sesi tanya jawab. Berdasarkan hasil pengamatan observer, persentase rata-rata aktivitas mahasiswa adalah $85,14 \%$ berada pada kategori baik.

Selain aktivitas siswa, observer juga mengamati aktivitas dosen. Data aktivitas dosen siklus III ditunjukkan pada Tabel 10.

Tabel 10. Data aktivitas dosen siklus III

\begin{tabular}{clccc}
\hline Tahap & \multicolumn{1}{c}{ Indikator } & $\begin{array}{c}\text { Skor per- } \\
\text { olehan }\end{array}$ & $\begin{array}{c}\text { Skor } \\
\text { Maksimal }\end{array}$ \\
\hline \multirow{2}{*}{ Awal } & Menyampaikan tujuan & 4 & 32 \\
\cline { 2 - 4 } & Memotivasi mahasiswa & 4 & 32 \\
\hline \multirow{2}{*}{ Mnti } & Menjelaskan materi pelajaran & 4 & 32 \\
\cline { 2 - 4 } & Memberikan kesempatan bertanya kepada mahasiswa & 3 & 32 \\
\cline { 2 - 4 } & $\begin{array}{l}\text { Membentuk kelompok mahasiswa dan membimbing } \\
\text { mahasiswa dalam belajar }\end{array}$ & 4 & 32 \\
\cline { 2 - 4 } & $\begin{array}{l}\text { Membagikan LKM dan mahasiswa mengisi LKM dan } \\
\text { membimbing mahasiswa dalam melakukan diskusi }\end{array}$ & 4 & 32 \\
\hline \multirow{2}{*}{ Akhir } & $\begin{array}{l}\text { Memberikan evaluasi kepada seluruh mahasiswa baik secara } \\
\text { individu maupun kelompok }\end{array}$ & 4 & 32 \\
\cline { 2 - 4 } & $\begin{array}{l}\text { Memberikan penghargaan kepada mahasiswa baik upaya } \\
\text { maupun hasil belajar individu dan kelompok }\end{array}$ & 3 & 32 \\
\hline
\end{tabular}

\begin{tabular}{rcc}
\hline Total Skor & 30 \\
\hline Persentase rata-rata & $\mathbf{9 3 , 7 5 \%}$
\end{tabular}

Kategori Sangat baik

Pada siklus II, aktivitas dosen terukur pada persentase rata-rata 93,75\% termasuk pada kategori sangat baik. Hal ini ditunjukkan dari kemampuan dosen dalam mengelola kelas meningkat pada hampir setiap aspek indikator.

Pada tahap refleksi, proses pembelajaran siklus III berjalan semakin baik. Hal ini ditunjukkan dari adanya peningkatan pada hasil belajar dan aktivitas mahasiswa, serta pada aktivitas dosen. Peningkatan tersebut telah memenuhi bahkan melampaui dari yang ditetapkan sebagai indikator keberhasilan penelitian. Data rangkuman hasil peningkatan tersebut ditunjukkan pada tabel 11.

Tabel 11. Data hasil indikator keberhasilan implementasi model pembelajaran STAD berbantuan LKM 


\begin{tabular}{lcccc}
\multicolumn{1}{c}{ Indikator keberhasilan } & \multicolumn{4}{c}{ Hasil } \\
\cline { 2 - 5 } & Prasiklus & Siklus I & Siklus II & Siklus III \\
\hline Nilai rata-rata hasil belajar & 50,36 & 61,02 & 73,07 & 85,14 \\
\hline \multirow{2}{*}{ Persentase rata-rata aktivitas mahasiswa (\%) } & & 64,86 & 74,17 & 85,14 \\
& & cukup & baik & baik \\
\hline \multirow{2}{*}{ Persentase rata-rata aktivitas dosen (\%) } & & 74,13 & 84,38 & 93,75 \\
& & baik & baik & sangat baik
\end{tabular}

Telah tercapainya seluruh indikator keberhasilan menghasilkan keputusan bahwa penelitian telah selesai dengan sangat baik.

\section{KESIMPULAN}

Hasil penelitian menunjukkan bahwa implementasi model pembelajaran STAD berbantuan LKM dapat meningkatkan hasil belajar Akuntansi Sektor Publik. Peningkatan dapat dilihat dari nilai rata-rata hasil belajar mahasiswa pada prasiklus sebesar 50,36, meningkat pada siklus I sebesar 61,02, meningkat pada siklus II sebesar 73,07, dan meningkat pada siklus III sebesar 85,31.

Hal lain yang diamati pada penelitian ini adalah aktivitas mahasiswa pada siklus I sebesar $64,86 \%$, meningkat pada siklus II sebesar $74,17 \%$, dan meningkat pada siklus III sebesar $85,14 \%$. Aktivitas dosen pada siklus I sebesar 74,13\%, meningkat pada siklus II sebesar $84,38 \%$, dan meningkat pada siklus III sebesar 93,75\%.

\section{DAFTAR RUJUKAN}

Arikunto, S. (2013). Prosedur Penelitian Suatu Pendekatan Praktik. Jakarta : PT Rineka Cipta.

Asmaningrum, HP., Gelong, MA., Werang, BR. (2018). Penerapan Media Peta Konsep terhadap Hasil Belajar Siswa SMA GERADUS ADII MERAUKE. Jurnal Inovasi Pendidikan Kimia, Volume 12, Nomor 2, 2018.

Asmaningrum, HP. (2017). Studi Komparasi Hasil Belajar Kimia Menggunakan Media LKM dan TTS melalui Implementasi Model Pembelajaran Kooperatif Tipe 
Irianto, Implementasi Model Pembelajaran STAD berbantuan LKM Untuk Meningkatkan Hasil Belajar...

Small Group Discussion (SGD). Jurnal Tadris Kimiya, Volume 2, Nomor 1, Juni 2017.

Depdiknas. (2006). Kurikulum Tingkat satuan Pendidikan. Jakarta: Dirjen Dikdasmen.

Esminarto, Sukowati, Suryowati, N, Anam, K. (2016). Implementasi Model STAD dalam Meningkatkan Hasil Belajar Siswa. Briliant: Jurnal Riset dan Konseptual, Volume 1, Nomor 1, November 2016.

Gusniar. (2014). Penerapan Model Pembelajaran Kooperatif Tipe Student Teams Achievment Division (STAD) Dalam Meningkatkan Hasil Belajar Siswa Pada Mata Pelajaran IPS Kelas IV SDN No. 2 Ogoamas II. Jurnal Kreatif Tadulako, Volume 2, Nomor 1, 2014.

Isjoni. (2010). Cooperative Learning Efektifitas Pembelajaran Kelompok. Bandung: Alfabeta.

Khusna, R. (2011). Upaya Peningkatan Hasil Belajar Siswa dengan Menggunakan Model Pembelajaran Kooperatif Tipe STAD. (Online), (http://rullykhusna-makalah-modelpembelajaran-stad.html), diakses tanggal 20 Januari 2019.

Nikmah, EH., Fatchan, A., dan Wirahayu, YA. (2013). Model Pembelajaran Student Teams Achievement Divisions (STAD), Keaktifan Dan Hasil Belajar Geografi Siswa Kelas X di SMA Negeri 1 Kesamben Blitar. Jurnal Pendidikan Geografi, Volume 2, Nomor 1. Universitas Negeri Malang.

Nordiawan, D., dan Hertianti, A. (2010). Akuntansi Sektor Publik. Jakarta: Salemba Empat.

Rusman, 2012. Model-Model Pembelajaran Mengembangkan Profesionalisme Guru. Jakarta PT. Rajagrafindo Persada.

Saraswati, NF., dan Djazari, M. (2018). Implementasi Metode Pembelajaran Small Group Discussion dapat meningkatkan Aktivitas Belajar Pada Kompetensi Dasar Jurnal Penyesuaian Siswa Kelas X Akuntansi SMK Muhammadiyah Kretek Tahun Ajaran 2017/2018. Jurnal Pendidikan Akuntansi Indonesia, Volume XVI, Nomor 2, 2018.

Sugiharti, S., Saputro, S.,\& Sugiharto. (2013). Studi Komparasi Penggunaan Media TTS dan LKS Pada Pembelajaran Kooperatif 
Irianto, Implementasi Model Pembelajaran STAD berbantuan LKM Untuk Meningkatkan Hasil Belajar...

Student Teams Achievement Divisions (STAD) Pada Materi Pokok Sistem Periodik Unsur Kelas X Semester Gasal SMA Negeri I Karanganyar Tahun Pelajaran 2012/2013. Jurnal Pendidikan Kimia, Volume 2, Nomor 1.

Trianto. (2011). Pengantar Penelitian Pendidikan bagi Pengembangan Profesi Pendidikan dan Tenaga Kependidikan. Jakarta: Kencana. 